\title{
Tables, Figures, and Photographs
}

\section{Map}

Downtown Flushing

\section{Tables}

1. Year of arrival in the United States, by class

60

2. Reasons for coming to the United States, by class

3. Means of finding first and current jobs in the United States, by class

4. Family performance of household tasks, by class

5. Number of households celebrating Chinese and American

6. Upward and downward mobility of workers since leaving Taiwan, by class

7. Class interaction in time of trouble

\section{Figures}

1. Crissman's segmentary model 9

2. Class structure of new Chinese immigrants 43

\section{Photographs}

Chinese businesses on 4oth Road in Flushing 37

A Chinese delicatessen $\quad 111$

$\begin{array}{ll}\text { The Reformed Church of Newtown } & 167\end{array}$

Neighborhood adopt-a-station program by the FCBA 193

$\begin{array}{ll}\text { The CAVA's voter registration } & 203\end{array}$

The QCWA Mother's Day celebration at Elmhurst-Jackson

Heights Senior Center

Grand opening of the ACWA's office

The CAPA Chinese Lunar New Year celebration $\quad 226$

China pavilion at the Queens Festival 235

Taiwanese culture pavilion at the Queens Festival 243 